\title{
Germline PTEN mutations are rare and highly penetrant
}

\author{
Cecilie F Rustad', Merete Bjørnslett', Ketil R Heimdal', Lovise Mæhle', Jaran Apold³ , Pål Møller' \\ ISection for Inherited Cancer, Department of Medical Genetics, Rikshospitalet-Radiumhospitalet Medical Centre, Oslo, Norway, 2 Section for Molecular Genetics, \\ Department of Medical Genetics, Rikshospitalet-Radiumhospitalet Medical Centre, Oslo, Norway, ${ }^{3}$ Centre for Medical Genetics and Molecular Medicine, Institute of \\ Clinical Medicine, University of Bergen, Norway
}

Key words: breast cancer, Cowden syndrome, PTEN, thyroid cancer

Corresponding author: Dr. P Møller, Section for Inherited Cancer, Department of Medical Genetics, Rikshospitalet-Radiumhospitalet Medical Center, N-0310 0slo, Norway, phone +47 2293567 5, fax +47 22935219 , Email: pal.moller@klinmed.uio.no

Submitted: 310 ctober 2006

Accepted: 5 December 2006

\begin{abstract}
Cowden syndrome (multiple hamartoma syndrome, MIM 158350) is an early onset syndrome characterized by multiple hamartomas in the skin, mucous membranes, breast, thyroid and endometrium. Patients with Cowden syndrome have increased risk of breast cancer, thyroid cancer and endometrial cancer. In 1997 germline mutations in PTEN were demonstrated to cause Cowden syndrome. We report the results of diagnostic and predictive testing in all families with Cowden syndrome or suspected Cowden syndrome registered at the Norwegian cancer family clinics. PTEN mutations were found in all six families meeting the clinical criteria for Cowden syndrome, in none of the two families assumed to have Cowden syndrome but not fulfilling the criteria, and in none of the eight families selected in our computerized medical files to have a combination of breast and thyroid cancers. Age-related penetrances for the various neoplasms are given. All families but one were small and de novo mutations were found.
\end{abstract}

\section{Introduction}

In 1963 Lloyd and Dennis described a patient named Rachel Cowden who died of bilateral breast cancer in her thirties [1]. Cowden syndrome is now recognized as an autosomal dominant syndrome characterized by multiple hamartomas originating from all three germ-cell layers. Mucocutaneous lesions including trichilemmomas are seen in $90-100 \%$ of patients [2]. There is increased risk of early breast cancer from 14 years of age, and lifetime risk is estimated to 25-50\% [3-5]. Goitre and thyroid adenomas are frequently seen and the estimated prevalence of thyroid cancer is $3-7 \%[3,6,7]$. We have previously reported endometrial cancer in one Norwegian family with Cowden syndrome [8].

In 1995 the International Cowden Syndrome Consortium was formed and a set of clinical diagnostic criteria were suggested; see Table 1 [2, 9, 10]. In 1997 the susceptibility gene for Cowden syndrome was identified on chromosome 10q23.3 and was found to be PTEN $[11,12]$. Germline mutations are found throughout the PTEN gene, the majority in exons 5, 7 and $8[2,13]$. The frequency of germline PTEN mutations, including mutations in the promoter region, in Cowden syndrome have been reported to approach 85-90\% [14]. Genotype/phenotype correlations have been suggested, but have not been confirmed [15-17]. 
Table 1. International Cowden Syndrome Consortium operational criteria (version 2000) as given by Charis Eng [2]

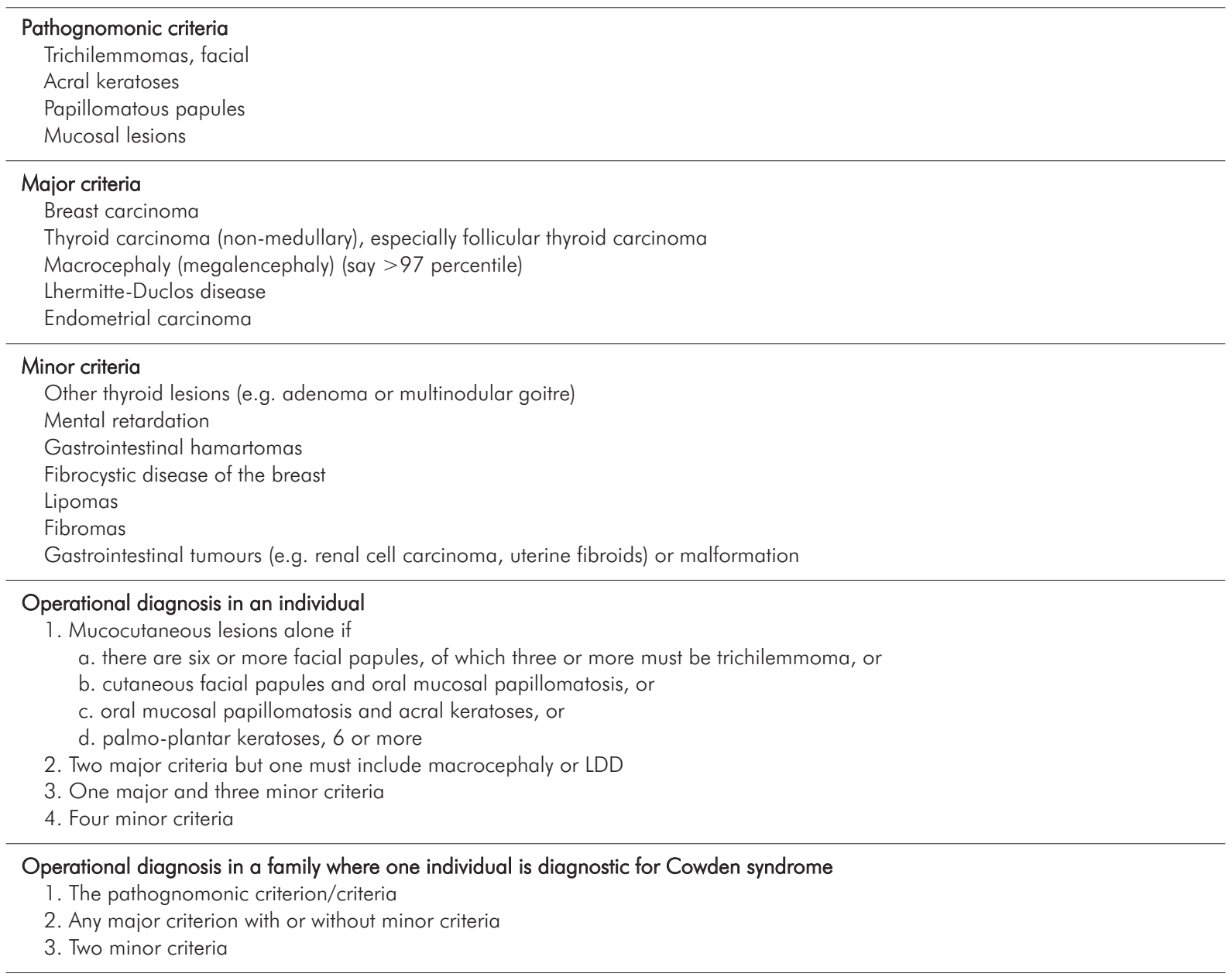

Nelen has estimated the incidence to be between 1 per 200,000 and 1 per 250,000 in the Dutch population [16].

As for all inherited cancer syndromes, the penetrance of the underlying genetic defects and the full clinical spectrum of their expressions have been difficult to assess without access to genetic testing.

Fifty to sixty percent of patients with Bannayan-RileyRuvalcaba syndrome (BRRS, MIM 153480) have been shown to have germline mutations in the PTEN gene $[14,18]$. An association between germline PTEN mutations and Proteus syndrome (MIM 176920) has been disputed [19-22].

Our aim was to validate strategies to identify families with PTEN mutations and to estimate prevalences and penetrances of PTEN mutations.

\section{Material and methods}

The computerized medical files at the Section for Inherited Cancer, Rikshospitalet-Radiumhospitalet
Medical Centre, include more than 40,000 patients belonging to more than 3,000 families. These files were analyzed and all families with a diagnosis of Cowden syndrome, all families suspected to have Cowden syndrome, and all families with a combination of breast and thyroid cancers were identified. All of the five other Norwegian genetic centres contributed their families with Cowden stigmata. The four families previously reported to harbour PTEN mutations were included.

We had no families with suspected Bannayan-RileyRuvalcaba syndrome, Proteus syndrome or Proteus-like syndrome. Our two patients with Lhermitte-Duclos disease were also classified as having Cowden syndrome and included above.

All families were extended and offered genetic testing according to our genetic health care standards [23]. Because all activity was provided as health service, all information was kept in the medical files and no research registry was created. All activities were according to 


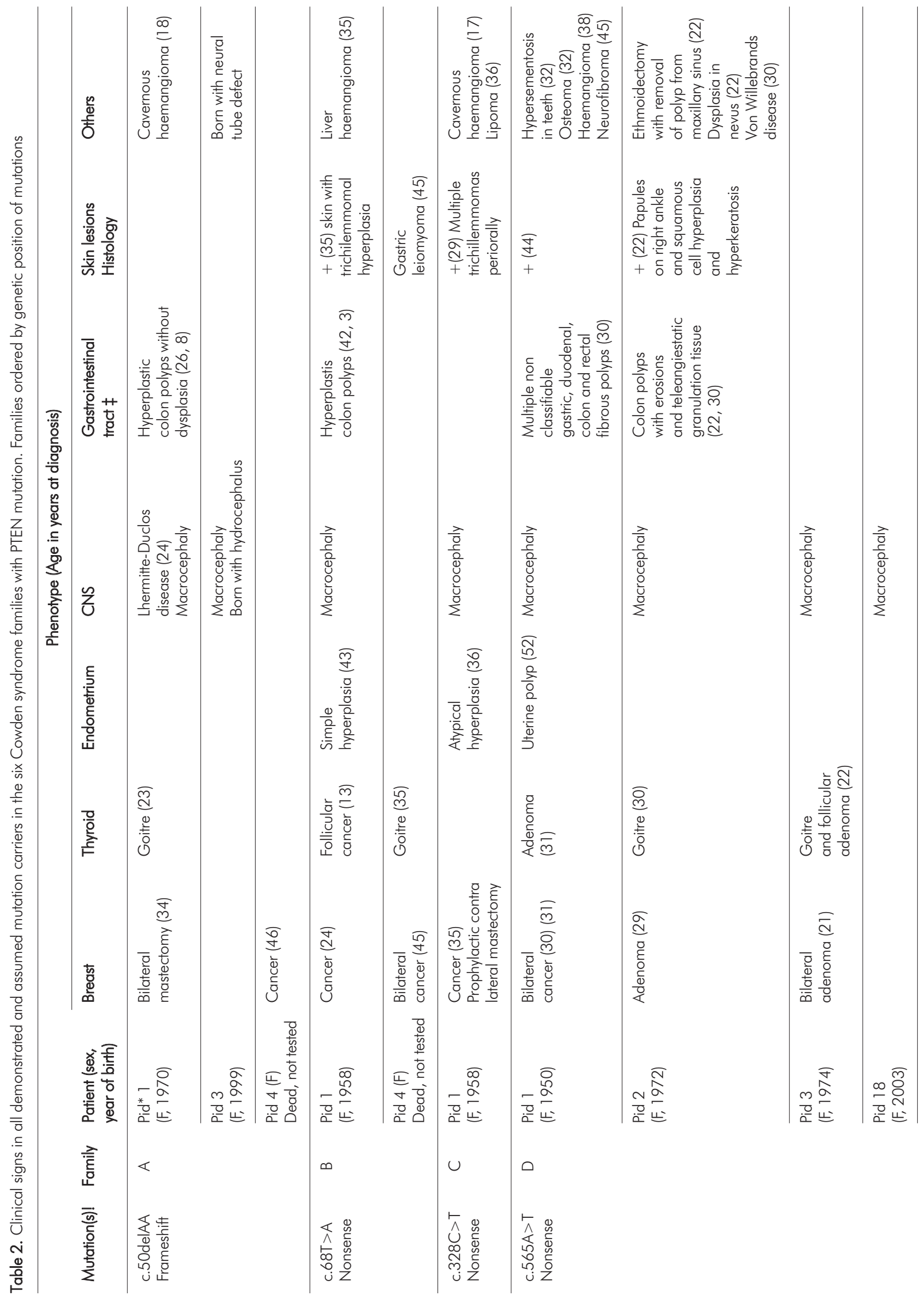




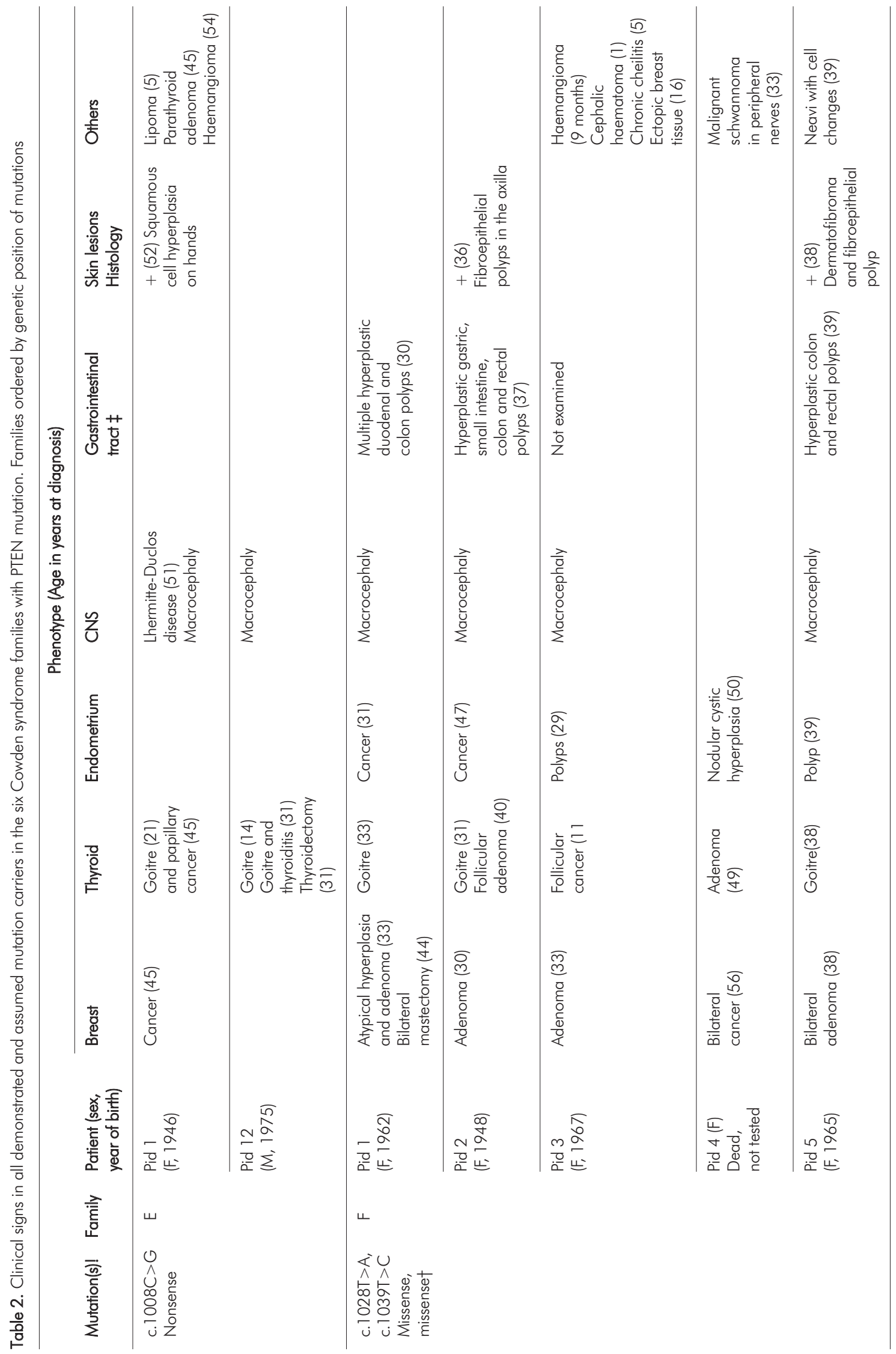




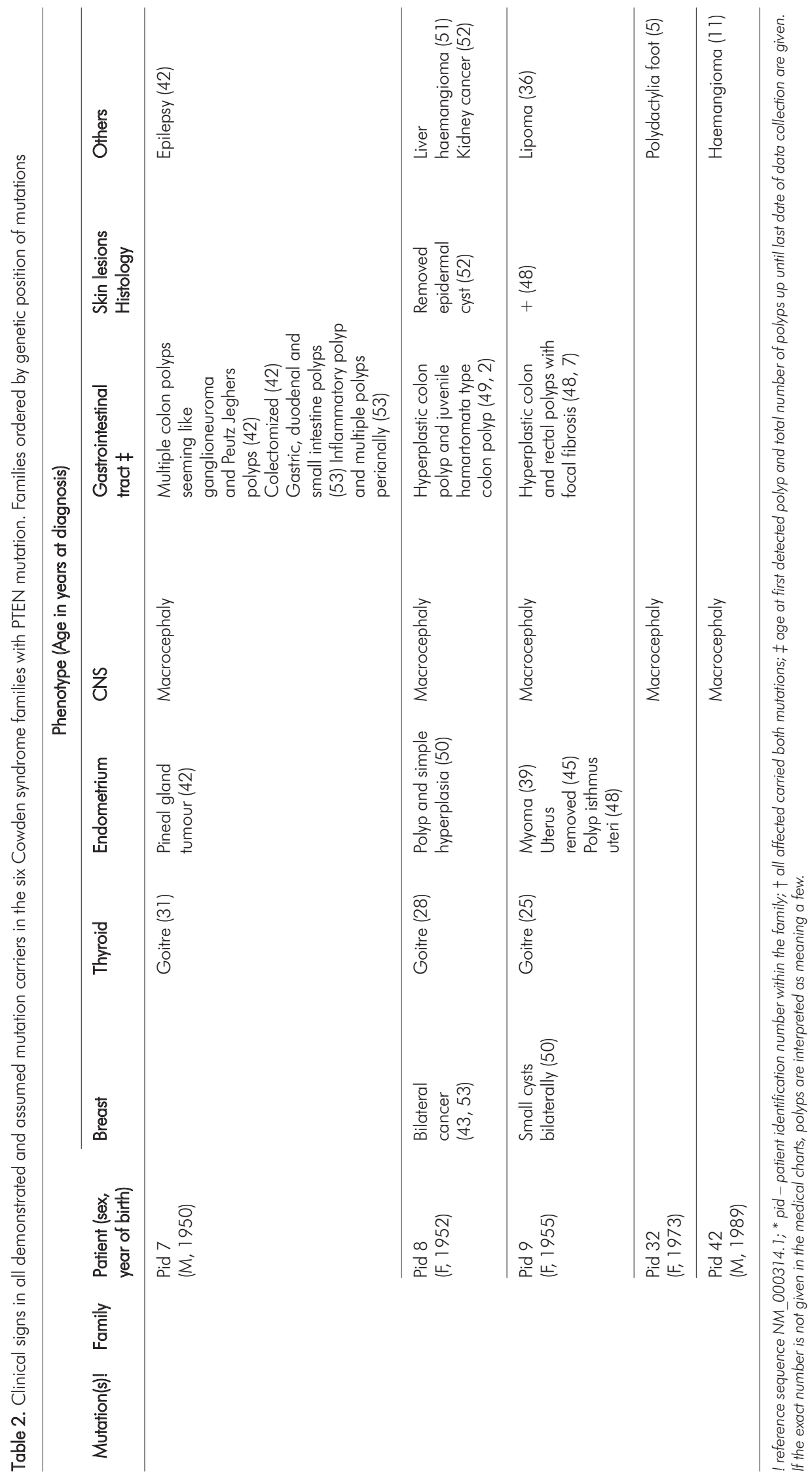


Norwegian legislation. All diagnoses were confirmed in the medical files after written informed consent from each patient if alive or from their relatives if dead. All family members were offered genetic counselling. All genetic testing was subjected to written informed consent.

We sequenced all nine exons, their flanking areas and 1500 basepairs upstream of ATG (the promoter region) in the PTEN gene in all patients examined.

Kaplan-Meier survival estimates were calculated using the computer program Systat $10^{\circ}$. The data were stored in Oracle ${ }^{\odot}$, pedigrees were displayed in Cyrillic $^{\odot}$ and the application to run the database as an electronic patient file system was programmed in $\mathrm{dB}+{ }^{\circ}$.

\section{Results}

We identified six families (family A, B, C, D, E and F) which fulfilled the International Cowden Syndrome Consortium Criteria; for details see Table 2. Four of them had been identified prior to the present study (B, C, D, F) [8]. Two families ( $G$ and $H)$ had been clinically assumed to have Cowden syndrome earlier on, but did not fulfil the diagnostic criteria. Eight families had a combination of breast cancer and thyroid cancer.

Mutations in the coding sequence of PTEN were identified in all living affected members of the six families fulfilling the International Cowden Syndrome Consortium Criteria. All together 56 persons were subjected to genetic testing, out of whom 19 were identified as mutation carriers. None of the 37 healthy relatives in these families had mutations. In the two families clinically assumed to have Cowden syndrome, but not fulfilling the clinical criteria, no PTEN mutation was identified; for details see Table 3. In the eight families selected by a combination of breast and thyroid cancer no PTEN mutation was identified. Different cancer types were seen in these families; for details see Table 3.

Of the tested families, five families had a frameshift or nonsense mutation and one family had two missense mutations located in exon 9 located on the same chromosome. The detected mutations were located in exon 1 (c.50delAA and c.68T>A), exon 5 (c.328C > T), exon 6 (c.565A>T), exon 8 (c. 1008C>G) and exon 9 (c. 1028T >A and c. 1039T >C) (reference sequence: NM 000314.1). No mutations were found in regulatory regions.

Except for one family $(F)$, the mutation carrying families were small. One family had a demonstrated de novo mutation (D) and two families most likely had de novo mutations ( $C$ and $E$ ). We did not observe skipped generations.

The mothers of three of our probands had had breast cancer at age 45 (bilateral breast cancer),
46 and 56 (bilateral breast cancer) years old. Since they all were deceased and our attempts to perform mutation analysis from paraffin embedded tissue from these patients were unsuccessful, they were considered to be mutation carriers by state.

All mutation carriers were examined and all had clinical signs. The youngest mutation carrier was born with a demonstrated clinical sign (macrocephaly, D-18). Most patients had more than one clinical sign; for details see Table 2. Twelve (63.2\%) patients had goitre and/or adenoma of the thyroid gland, ten $(52.6 \%)$ patients had polyps of the gastrointestinal tract, seven (36.8\%) patients had benign tumours of the breast, seven (36.8\%) patients had endometrial polyps and/or hyperplasia; for details see Table 3. Fig. 1 shows age-related distribution of first clinical sign, as estimated by the Kaplan-Meier algorithm.

One patient (A-1) had multiple small colonic polyps interpreted as not having any dysplasia at age 33. Two years later she still had multiple small polyps less than 5 millimetres in diameter, now histologically described as lymphoid infiltrations and interpreted as an inflammatory condition. Mutation analysis of the APC gene showed APC 7542 G>A, G2502S and APC $1496 \mathrm{C}>\mathrm{T}, \mathrm{Y} 486 \mathrm{Y}$, interpreted as normal variation. $\mathrm{MYH}$ testing was normal.

Macrocephaly is defined as a head circumference above the $97^{\text {th }}$ percentile [2]. We used centile charts for Norwegian boys and girls aged 0-17 and for all patients above 17 years of age we used the centile for age 17. All our patients that were alive were clinically assessed to have macrocephaly. Macrocephaly was confirmed by exact measurement in 15 patients and judged to be clinically present in the remaining four.

Cancer appeared from age 11. The oldest mutation carrier without diagnosed neoplasia was 49 years old. She had, however, been hysterectomized at age 45 . Five (26.3\%) patients had breast cancer, age range from 24 to 45 years. Three (15.8\%) patients had thyroid cancer, age range 11 -45 years. Three (15.8\%) patients had tumours of the brain (two had a gangliocytoma at age 24 and 51 and one had a tumour of the pineal gland at age 42). Two (10.5\%) patients had endometrial cancer at 31 and 47 years of age. One (5.3\%) patient had kidney cancer at 52 years of age. For details, see Table 3. Results of Kaplan-Meier analysis for age of onset of cancer are given in Fig. 2.

\section{Discussion}

Cowden syndrome is rarely found in families attending our cancer genetics clinic. In the national 
Table 3. Number of patients with benign neoplasms and different cancer types, and the age range

\begin{tabular}{|c|c|c|c|c|c|c|}
\hline & \multicolumn{2}{|c|}{$\begin{array}{l}\text { PTEN mutation positive families } \\
\text { fulfilling the Cowden syndrome } \\
\text { criteria ( } 6 \text { families, only } \\
\text { demonstrated mutation } \\
\text { carriers included) }\end{array}$} & \multicolumn{2}{|c|}{$\begin{array}{l}\text { Assumed Cowden syndrome } \\
\text { families but not fulfilling } \\
\text { the criteria, no PTEN } \\
\text { mutation detected } \\
\text { ( } 2 \text { families) }\end{array}$} & \multicolumn{2}{|c|}{$\begin{array}{l}\text { Breast- and thyroid-cancer } \\
\text { kindreds, no PTEN mutation } \\
\text { detected ( } 8 \text { families) }\end{array}$} \\
\hline & $\begin{array}{l}\text { Number } \\
\text { of patients }\end{array}$ & $\begin{array}{l}\text { Median/Mean age } \\
\text { (range) years }\end{array}$ & $\begin{array}{l}\text { Number } \\
\text { of patients }\end{array}$ & $\begin{array}{l}\text { Median/Mean age } \\
\text { (range) years }\end{array}$ & $\begin{array}{l}\text { Number } \\
\text { of patients }\end{array}$ & $\begin{array}{l}\text { Median/Mean age } \\
\text { (range) years }\end{array}$ \\
\hline \multicolumn{7}{|l|}{ Benign neoplasms } \\
\hline Goitre and/or adenoma & 12 & $29 / 27.25(14-38)$ & & & $1^{* *}$ & 34 \\
\hline Polyps of Gl tract & 10 & $38 / 36.5(22-49)$ & & & & \\
\hline Haemangioma & 8 & $26.5 / 28.1(0.75-54)$ & & & & \\
\hline Mucocutaneous lesions & 9 & $36 / 36.6(22-52)$ & 1 & 59 & & \\
\hline Endometrial polyps/simple hyperplasia & 7 & $43 / 42.4(29-52)$ & & & & \\
\hline Benign tumours of the breast & 7 & $33 / 33.4(21-50)$ & & & $1^{* *}$ & 25 \\
\hline Lipoma & 3 & $36 / 27.3(10-36)$ & & & & \\
\hline \multicolumn{7}{|l|}{ Cancers } \\
\hline Breast & $5^{*}$ & $35 / 35.4(24-45)$ & 4 & $42.5 / 46.5(25-76)$ & 12 & $50.5 / 52(40-65)$ \\
\hline Thyroid & 3 & $13 / 23(11-45)$ & 5 & $50 / 49.2(24-84)$ & 11 & $45 / 46.4(22-83)$ \\
\hline Brain & $3+$ & $42 / 39$ (24-51) & & & & \\
\hline Endometrial & 2 & $39 / 39$ (31-47) & & & 1 & 67 \\
\hline Kidney & 1 & 52 & 1 & 27 & & \\
\hline Testicular & & & 1 & 62 & & \\
\hline Mediastinal & & & 1 & 54 & & \\
\hline Ovarian & & & & & 2 & $51.5 / 51.5(49-54)$ \\
\hline Colon & & & & & 2 & $57 / 57(49-65)$ \\
\hline Prostate & & & & & 1 & 58 \\
\hline Histiocytoma & & & & & 1 & 45 \\
\hline Malignant melanoma & & & & & 2 & $57.5 / 57.7(56-59)$ \\
\hline Cervical & & & & & 1 & 34 \\
\hline Adrenal & & & & & 1 & 56 \\
\hline
\end{tabular}

* two patients had bilateral disease, scored for age at first cancer; † two patients had a gangliocytoma (Lhermitte-Duclos disease), one had a tumour of the pineal gland; ${ }^{* *}$ same patient.

survey presented here, PTEN mutations were found in all families fully meeting the Cowden syndrome criteria, but in no Cowden syndrome-like families not meeting the criteria. Penetrance of PTEN mutations was high and expressions were Cowden syndrome stigmata in early infancy or childhood and cancer in adolescence or early adulthood [24, 25]. In addition, the families were small with demonstrated de novo mutations, indicating low fitness before modern treatment and low population burden of mutation carriers.
Ten years ago we reported the well defined Cowden syndrome families we knew at the time at RikshospitaletRadiumhospitalet Medical Centre [8]. The national survey presented here revealed just two additional families, both fulfilling the clinical criteria for Cowden syndrome. Obviously, the numbers are too small to arrive at conclusions with respect to clinical manifestations in the mutation carriers. On the other hand, we had a large sample of cancer families initially not ascertained through Cowden criteria - the families may be representative for families selected this way. On the other hand, we did not 


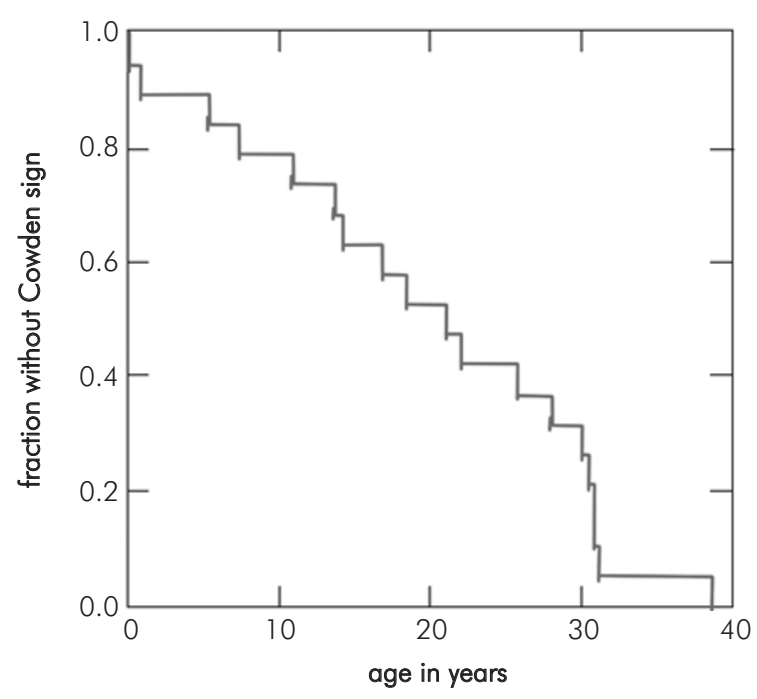

Fig. 1. Age at onset of first clinical sign estimated by Kaplan-Meier algorithm for demonstrated mutation carriers. See Table 2 for details of clinical signs

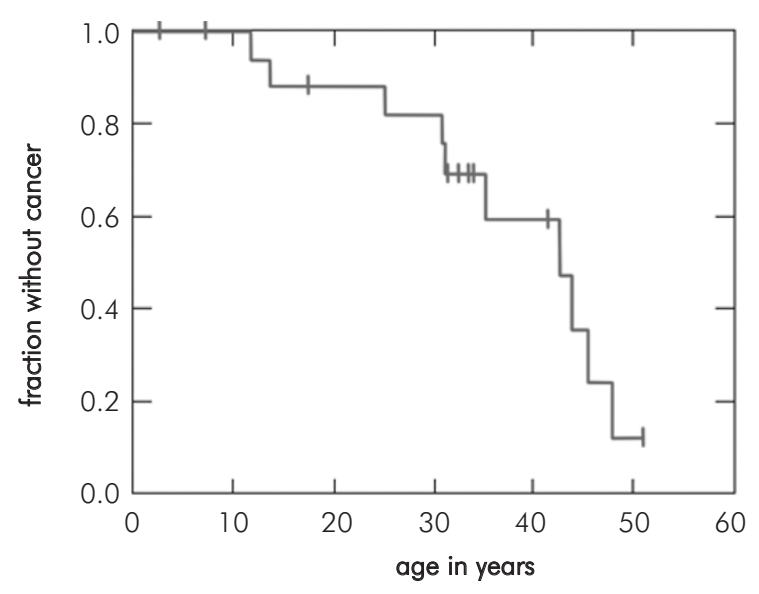

Fig. 2. Age at onset of first cancer estimated by Kaplan-Meier algorithm for demonstrated mutation carriers

search for Cowden syndrome without cancer. We described that in familial cancer all mutation carrying families had additional Cowden syndrome stigmata. We have not examined whether or not Cowden syndromelike families without cancer may have PTEN mutations. We have previously reported on frequent cancer syndromes in Norway; we have a large number of cancer kindreds in our computerized database, and we found no additional families when searching for Cowden syndrome associated cancers. We consider the low prevalence and the expressions found representative for Cowden families with cancer.
All families (100\%, 95\% Cl 37-100\%) which fulfilled the Cowden syndrome criteria carried PTEN mutations, which is in keeping with the previously reported estimate of 85-90\%.[14] Our observed number of mutation carriers gives an observed prevalence of 1 per 242,063, which is within Nelen's estimate of between 1 per 200,000 and 1 per 250,000 [16]. We found only six families with mutations, which were considered too few for meaningful considerations with respect to where in the gene the mutations were located.

Twelve (63.2\%) patients had benign thyroid manifestations, which is a little less than three quarters reported by Merg [7]. The youngest age of onset for thyroid cancer was 11 years, which indicates that PTEN mutation carriers contract thyroid cancer both more frequently and at a younger age than the general population. Seven (36.8\%) patients had benign breast lesions, compared to earlier reports of $50-60 \%[3,6]$. Five out of 19 (26.3\%) had breast cancer at $24-45$ years, which is within $20-30 \%$ and age range as previously reported [4]. Two (10.5\%) patients had endometrial cancer compared to earlier reports of $6 \%[3,7]$. Ten (52.6\%) patients had gastrointestinal polyps, which is close to earlier reports [7]. None of our mutation carriers had colon cancer. According to Lynch and de la Chapelle a firm association between Cowden syndrome and colorectal cancer has yet to be identified, and according to Eng colorectal cancers are not components of Cowden syndrome $[26,27]$. One $(5.3 \%)$ of our mutation carriers had renal cell carcinoma, supporting the notion that renal cell carcinoma should be added to the operational criteria for Cowden syndrome [28]. Thus, our findings add empirical support to established conclusions which have been questioned because of low numbers reported.

Nine of 19 (47\%) mutation carriers were members of one kindred. We consider this a finding corresponding with low and variable fitness in mutation carriers. If so, the uneven distribution of mutation carriers in families was a finding and possibly not a statistical problem reflecting random variation in low numbers.

In sum, our results were that Cowden syndrome families had PTEN mutations, while Cowden-like families and breast and thyroid cancer kindreds did not. The number of Cowden syndrome-like families was not more than what might be expected by chance alone. All examined mutation carriers had clinical signs, and cancer started to occur before the age of 16 .

In Cowden syndrome families, genetic testing to identify individuals at risk of contracting cancer cannot wait until the kindreds are old enough to give informed consent. We find it reasonable to offer genetic testing 
in infancy/early childhood. Mutation carriers may be offered thyroid screening from childhood, and breast cancer screening may be considered from adolescence (with MRI, to avoid radiation exposure by mammography in puberty). Our material is not large enough to conclude on which age to start breast cancer screening, but the youngest patient with breast cancer described internationally was 14 years old [3]. We feel that we should try to do our best when it comes to screening, and therefore we recommend that one may consider breast cancer screening from adolescence.

Non-mutation carriers and members of Cowden syndrome-like families may not be at risk for cancer in early age, and may need no special health care in infancy or adolescence. Thorough clinical genetic workup of families and access to genetic testing will discriminate between those who need health service from childhood, and those who do not.

\section{References}

1. Lloyd KM 2nd, Dennis M. Cowdens's disease. A possible new symptom complex with multiple system involvement. Ann Intern Med 1963; 58: 136-142.

2. Eng C. Cowden syndrome and related disorders. In: Morrison PJ, Hodgson SV, Haites NE (eds.). Familial Breast and Ovarian Cancer. Genetics, Screening and Management. Cambridge, UK: 2002: 22-42.

3. Starink TM, van der Veen JP, Arwert F, de Waal LP, de Lange GG, Gille JJ, Eriksson AW. The Cowden syndrome: a clinical and genetic study in 21 patients. Clin Genet 1986; 29: 222-233.

4. Longy M, Lacombe D. Cowden disease. Report of a family and review. Ann Genet 1996; 39: 35-42.

5. Eng C. Cowden syndrome. J Genet Couns 1997; 6: 181-191.

6. Hanssen AM, Fryns JP. Cowden syndrome. J Med Genet 1995; 32: 117-119.

7. Merg A, Howe JR. Genetic conditions associated with intestinal juvenile polyps. Am J Med Genet C Semin Med Genet 2004; 129: 44-55

8. Lynch ED, Ostermeyer EA, Lee MK, Arena JF, Ji H, Dann J, Swisshelm K, Suchard D, MacLeod PM, Kvinnsland S, Gjertsen BT, Heimdal K, Lubs H, Moller P, King MC. Inherited mutations in PTEN that are associated with breast cancer, cowden disease, and juvenile polyposis. Am J Hum Genet 1997; 61: 1254-1260.

9. Nelen MR, Padberg GW, Peeters EA, Lin AY, van den Helm B, Frants RR, Coulon V, Goldstein AM, van Reen MM, Easton DF, Eeles RA, Hodgsen S, Mulvihill JJ, Murday VA, Tucker MA, Mariman EC, Starink TM, Ponder BA, Ropers HH, Kremer $\mathrm{H}_{\text {, }}$ Longy $M$, Eng $C$. Localization of the gene for Cowden disease to chrmosome 10q22-23. Nat Genet 1996; 13: 114-116.

10. Eng C. Genetics of Cowden syndrome: through the looking glass of oncology. Int J Oncol 1998; 12: 701-710.

11. Nelen MR, van Staveren WC, Peeters EA, Hassel MB, Gorlin RJ, Hamm H, Lindboe CF, Fryns JP, Sijmons RH, Woods DG, Mariman EC, Padberg GW, Kremer H. Germline mutations in the PTEN/MMACl gene in patients with Cowden disease. Hum Mol Genet 1997; 6: 1383-1387.

12. Liaw D, Marsh DJ, Li J, Dahia PLM, Wang SI, Zheng Z, Bose S, Call KM, Tsou HC, Peacocke M, Eng C, Parsons R. Germline mutations of the PTEN gene in Cowden disease, an inherited breast and thyroid cancer syndrome. Nat Genet 1997; 16: 64-67.
13. Harada N, Sugimura T, Yoshimura R, Motomura S, Shirahama S, Naramoto J, Chijiiwa Y, Nakamura K, Ito K, Nawata H. Novel germline mutation of the PTEN gene in a Japanese family with Cowden disease. J Gastroenterol 2003; 38: 87-91.

14. Pilarski R, Eng C. Will the real Cowden syndrome please stand up (again)? Expanding mutational and clinical spectra of the PTEN hamartoma tumour syndrome. J Med Genet 2004; 41 : 323-326.

15. Marsh DJ, Coulon V, Lunetta KL, Rocca-Serra P, Dahia PL, Zheng Z, Liaw D, Caron S, Duboue B, Lin AY, Richardson AL, Bonnetblanc JM, Bressieux JM, Cabarrot-Moreau A, Chompret A, Demange L, Eeles RA, Yahanda AM, Fearon ER, Fricker JP, Gorlin RJ, Hodgson SV, Huson S, Lacombe D, Eng C, et all. Mutation spectrum and genotype-phenotype analyses in Cowden disease and Bannayan-Zonana syndrome, two hamartoma syndromes with germline PTEN mutation. Hum Mol Genet 1998; 7: 507-515.

16. Nelen MR, Kremer H, Konings IB, Schoute F, van Essen AJ, Koch R, Woods CG, Fryns JP, Hamel B, Hoefsloot LH, Peeters EA, Padberg GW. Novel PTEN mutations in patients with Cowden disease: absence of clear genotype-phenotype correlations. Eur J Hum Genet 1999; 7: 267-273.

17. Sawada T, Okada T, Miwa K, Satoh H, Asano A, Mabuchi H. Two novel mutations of PTEN gene in Japanese patients with Cowden syndrome. Am J Med Genet A 2004; 128: 12-14.

18. Marsh DJ, Kum JB, Lunetta KL, Bennett MJ, Gorlin RJ, Ahmed SF, Bodurtha J, Crowe C, Curtis MA, Dasouki M, Dunn T, Feit H, Geraghty MT, Graham JM Jr, Hodgson SV, Hunter A, Korf BR, Manchester D, Miesfeldt S, Murday VA, Nathanson KL, Parisi $M$, Pober $B$, Romano $C$, Eng $C$, et all. PTEN mutation spectrum and genotype-phenotype correlations in Bannayan-RileyRuvalcaba syndrome suggest a single entity with Cowden syndrome. Hum Mol Genet 1999; 8: 1461-1472.

19. Zhou X, Hampel H, Thiele H, Gorlin RJ, Hennekam RC, Parisi $M$, Winter RM, Eng C. Association of germline mutation in the PTEN tumour suppressor gene and Proteus and Proteus-like syndromes. Lancet 2001 ; 358: $210-11$.

20. Smith JM, Kirk EP, Theodosopoulos G, Marshall GM, Walker J, Rogers M, Field M, Brereton JJ, Marsh DJ. Germline mutation of the tumour suppressor PTEN in Proteus syndrome. J Med Genet 2002; 39: 937-940.

21. Biesecker LG Rosenberg MJ, Vacha S, Turner JT, Cohen MM. PTEN mutations and proteus syndrome. Lancet 2001 ; 358: 2079-2080.

22. Cohen MM Jr, Turner JT, Biesecker LG. Proteus syndrome: misdiagnosis with PTEN mutations. Am J Med Genet A 2003; 122: 323-324.

23. Moller P, Evans G, Haites N, Vasen H, Reis MM, Anderson E, Apold J, Hodgson S, Eccles D, Olsson H, Stoppa-Lyonnet D, Chang-Claude J, Morrison PJ, Bevilacqua G, Heimdal K, Mæhle L, Lalloo F, Gregory H, Preece P, Borg A, Nevin NC, Caligo M, Steel CM. Guidelines for follow-up of woman at high risk for inherited breast cancer: consensus statement from the Biomed 2 Demonstration Programme on Inherited Breast Cancer. Dis Markers 1999; 15: 207-211

24. Marsh DJ, Dahia PL, Caron S, Kum JB, Frayling IM, Tomlinson IP, Hughes KS, Eeles RA, Hodgson SV, Murday VA, Houlston R, Eng C. Germline PTEN mutations in Cowden syndrome-like families. J Med Genet 1998; 35: 881-885.

25. FitzGerald MG, Marsh DJ, Wahrer D, Bell D, Caron S, Shannon KE, Ishioka C, Isselbacher KJ, Garber JE, Eng C, Haber DA. Germline mutations in PTEN are an infrequent cause of genetic predisposition to breast cancer. Oncogene 1998; 17: 727-731.

26. Lynch HT, de la Chapelle A. Hereditary colorectal cancer. N Engl J Med 2003; 348: 919-932.

27. Eng C. Constipation, polyps, or cancer? Let PTEN predict your future. Am J Med Genet A 2003; 122: 315-322.

28. Eng $C$. Will the real Cowden syndrome please stand up: revised diagnostic criteria. J Med Genet 2000; 37: 828-830. 